\title{
THERMOLYSIS OF SURFACE-IMMOBILIZED PHENETHYL PHENYL ETHER*
}

\author{
P. F. Britt, A. C. Buchanan, III, and V. M. Hitsman \\ Chemistry Division \\ Oak Ridge National Laboratory \\ P. O. Box 2008 \\ Oak Ridge, TN 37831-6197
}

To be printsd in the proceedings of the American Chemical Society Meeting, Atlanta, GA, April 14-19,1991.

\section{DISCLAIMER}

This report was prepared as an account of work sponsored by an agency of the United States Government. Neither the United States Government nor any agency thereof, nor any of their employees, makes any warranty, express or implied, or assumes any legal liability or responsibility for the accuracy, completeness, or usefulness of any information, apparatus, product, or process disclosed, or represents that its use would not infringe privately owned rights. Reference herein to any specific commercial product, process, or service by trade name, trademark, manufacturer, or otherwise does not necessarily constitute or imply its endorsement, recommendation, or favoring by the United States Government or any agency thereof. The views and opinions of authors expressed herein do not necessarily state or reflect those of the United States Government or any agency thereof.

"Research was sponsored by the Division of Chemical Sciences, Office of Basic Energy Sciences, U. S. Department of Energy under contract DE-AC05840R21400 with Martin Marietta Energy Systems, Inc. VMH was supported by Oak Ridge Associated Universities Undergraduate Research Participation Program. 


\author{
P. F. Britt, A. C. Buchanan, III, and V. M. Hitsman \\ Chemistry Division \\ Oak Ridge National Laboratory \\ P. O. Box 2008 \\ Oak Ridge, TN 37831-6197
}

\title{
ABSTRACT
}

Our research has focused on modeling the constraints on free-radical reactions that might be imposed in coal as a consequence of its cross-linked macromolecular structure by covalently bonding diphenylalkanes to an inert silica surface. A surface-immobilized phenethyl phenyl ether ( $\approx \mathrm{PhCH}_{2} \mathrm{CH}_{2} \mathrm{OPh}$, or $\approx \mathrm{PPE}-3$ ) has been prepared as a model for ether linkages in lignin by the condensation of $\mathrm{p}-\mathrm{HOPhCH} \mathrm{CH}_{2} \mathrm{OPh}$ with the surface hydroxyls of a high purity fumed silica. Thermolysis of $\approx P P E-3$ at saturation surface coverage at $375^{\circ} \mathrm{C}$ produces $\approx \mathrm{PhCH}=\mathrm{CH}_{2}$ and $\mathrm{PhOH}$ as the major products which are consistent with the proposed free-radical chain mechanism for the decomposition of fluid-phase phenethyl phenyl ether. However, significant quantities of $\approx \mathrm{PhCH}_{3}$ and $\mathrm{PhCHO}$ (ca. $18 \%$ of the products) are prinduced indicating the emergence of a new reaction pathway on the surface. The mechanism for the decomposition of $\approx$ PPE-3 will be discussed in light of this new information.

Keywords: thermolysis, model compounds, mechanisms, restricted diffusion

\section{INTRODUCTION}

Attempts to probe the fundamental chemical reactions responsible for the thermal conversion of coal into liquid products has been hampered by the complex heterogeneous macromolecular structure of coal. Our efforts have focused on modelling the impact of restricted diffusional mobility on the thermal reactivity of coa! by covalently bonding model compounds representing structural features in coal to an inert silica surface. Thus far, our research has focused on the thermally induced free radical decomposition of $\alpha, \omega$-diphenylalkanes $\left(\mathrm{Ph}\left(\mathrm{CH}_{2}\right)_{n} \mathrm{Ph}\right.$ where $\left.\mathrm{n}=0-4\right)$ at 345$400{ }^{\circ} \mathrm{C} .1-5$ The results have shown that significant perturbations can occur in free radical reaction mechanisms which can alter reaction rates and product selectivities compared to the corresponding fluid phase behavior. We now have initiated a study on the the effects of restricted mass transport on the thermal decomposition of ether bridges which are prevalent in low rank coals and lignites. Although ether linkages are more thermally labile than the corresponding carbon analogues, $i_{i}$ has been observed that 
under liquefaction conditions optimized for bituminous coals, low rank coals and lignites afford low liquefaction yields. 6 It has been proposed that cross-linking reactions associated with oxygen functional groups $(-O H$, $-\mathrm{OCH}_{3}$, and $-\mathrm{COOH}$ ) are responsible for the low yields.6,7 In order to better understand the chemical reactions leading to retrograde processes, the effects of restricted diffusion of the thermolysis of surface-attached phenethyl phenyl ether $\left(\approx P h \mathrm{PH}_{2} \mathrm{CH}_{2} \mathrm{OPh}, \approx P P E-3\right)$ has been studied. Although the thermal decomposition of phenethyl phenyl ether (PPE) has been previously studied in the gas phase, $8,9 \mathrm{a}$ liquid phase, $9 \mathrm{a}$ and in the presence of tetralin, 8,10 hydrogen, 10,11 and metal catalysts, 11 our results show that a previously undetected free radical decomposition pathway is available for the thermal cracking of $\approx$ PPE.

\section{EXPERIMENTAL}

Surface-immobilized phenethyl phenyl ether ( $\approx P P E-3)$ was prepared at saturation surface coverage by the condensation of $p-\mathrm{HOC}_{6} \mathrm{H}_{4} \mathrm{CH}_{2} \mathrm{CH}_{2} \mathrm{OPh}$ (2.25 equiv) with the surface hydroxyl groups of a high purity fumed amorphous silica (Cab-O-Sil, grade M-5, Cabot Corp., $200 \mathrm{~m}^{2} \mathrm{~g}^{-1}$, ca. $4.5 \mathrm{OH}$ $\mathrm{nm}^{-2}$ ) at $222{ }^{\circ} \mathrm{C}$ for $30 \mathrm{~min}$ as previously described.1-3 The excess phenol was sublimed from the sample by heating for $70 \mathrm{~min}$ at $254^{\circ} \mathrm{C}$ under vacuum ( $3 \times 10-3$ Torr). The surface-attached PPE was liberated from the silica as the phenol by a base hydrolysis procedure, silylated to the trimethylsilyl ether, and analyzed by GC and GC/MS. The surface coverage was $0.562 \mathrm{mmol}$ of $\approx$ PPE-3 per gram of derivatized silica with the purity of recovered phenol $>99.9 \%$ by GC. The starting phenol, $p-\mathrm{HOC}_{6} \mathrm{H}_{4} \mathrm{CH}_{2} \mathrm{CH}_{2} \mathrm{OPh}$, was prepared in four steps trom $p-\mathrm{HOC}_{6} \mathrm{H}_{4} \mathrm{CH}_{2} \mathrm{CH}_{2} \mathrm{OH}$ by selective benzylation of the phenol with $\mathrm{K}_{2} \mathrm{CO}_{3}$ and $\mathrm{PhCH}_{2} \mathrm{Br}$ in dimethyl formamide, conversion of the alcohol to the tosylate with tosyl chloride in pyridine, base catalyzed alkylation of phenol with the tosylate using $\mathrm{K}_{2} \mathrm{CO}_{3}$ and $\mathrm{PhOH}$ in dimethyl formamide, and debenzylation by catalytic hydrogenolysis using $\mathrm{Pd} / \mathrm{C}$ in HOAC with $10 \%$ $\mathrm{H}_{2} \mathrm{SO}_{4}$. Repeated crystallizations from benzene/hexanes afforded p- $\mathrm{HOC}_{6} \mathrm{H}_{4} \mathrm{CH}_{2} \mathrm{CH}_{2} \mathrm{OPh}$ in $>99.9 \%$ purity by $\mathrm{GC}$.

Thermolysis of $\approx$ PPE-3 was preformed at $375 \pm 1{ }^{\circ} \mathrm{C}$ in T-shaped tubes sealed under high vacuum (ca. 10.6 Torr). The volatile products were collected as they formed in a cold trap ( $77 \mathrm{~K}$ ), analyzed by GC and GC/MS, and quantitated by the use of internal standards with measured GC detector response factors. The surface-attached products were removed from the silica as the corresponding phenols by a base hydrolysis procedure, silylated to the trimethylsilyl ethers, and analyzed as above. All products were identified by the mass spectra and whenever possible, by comparison with an authentic sample. 


\section{RESULTS AND DISCUSSION}

Thermolysis of $\approx \mathrm{PPE}-3$ at $375{ }^{\circ} \mathrm{C}$ has been studied at saturation coverage from ca. $1-17 \%$ conversion. At low conversion, $\approx P P E-3$ cracks to from approximately equal amounts of phenol plus surface-attached styrene $\left(\approx \mathrm{PhCH}=\mathrm{CH}_{2}\right.$ ) as the major products (ca. $81 \mathrm{~mol} \%$ ) and benzaldehyde plus surface-attached toluene $\left(\approx \mathrm{PhCH}_{3}\right)$ as minor products (ca. $\left.18 \mathrm{~mol} \%\right)$. A trace amount of surface-attached ethylbenzene $\left(\approx \mathrm{PhCH}_{2} \mathrm{CH}_{3}\right.$, ca. $\left.1.5 \mathrm{~mol} \%\right)$ was also detected. The conversion dependence of the products is shown in Figure 1.

$$
\begin{aligned}
\approx \mathrm{PhCH}_{2} \mathrm{CH}_{2} \mathrm{OPh} \rightarrow & \approx \mathrm{PhCH}=\mathrm{CH}_{2}+\mathrm{PhOH}+\approx \mathrm{PhCH}_{2} \mathrm{CH}_{3} \\
& \approx \mathrm{PhCH}_{3}+\mathrm{PhCHO}
\end{aligned}
$$

Thormolysis of phenethyl phenyl ether (PPE) in the gas or liquid phase at low conversions at $325-400{ }^{\circ} \mathrm{C}$ has been reported to yield $\mathrm{PhOH}$ and $\mathrm{PhCH}=\mathrm{CH}_{2}$ as

$$
\mathrm{PhCH}_{2} \mathrm{CH}_{2} \mathrm{OPh} \rightarrow \mathrm{PhCH}=\mathrm{CH}_{2}+\mathrm{PhOH}
$$

the major products (eq 2).8,9 Although minor amounts of $\mathrm{PhCH}_{3}$ and $\mathrm{PhCH}_{2} \mathrm{CH}_{3}$ have been detected, they were attributed to secondary decomposition of $\mathrm{PhCH}=\mathrm{CH}_{2} .{ }^{8}$ However, benzaldehyde has not been reported from the thermal decomposition of PPE in the gas, liquid phase, or in the presence of hydrogen donors. In the thermolysis of $\approx \mathrm{PPE}-3, \approx \mathrm{PhCH}_{3}$ does not appear to be a secondary product formed at the expense of the surfaceattached styrene as shown in Figure 1. The rate of decomposition of PPE in the liquid phase at $350-390{ }^{\circ} \mathrm{C}$ is similar to that of the carbon analogue 1,3diphenylpropane $\left(\mathrm{Ph}\left(\mathrm{CH}_{2}\right)_{3} \mathrm{Ph}, \mathrm{DPP}\right)^{9}$ and can be accelerated by the addition of benzyl phenyl ether. Likewise, the rate of decomposition of $\approx P P E-3$ at $375{ }^{\circ} \mathrm{C}\left(8.3 \% \mathrm{~h}^{-1}\right)$ is similar to that of surface-attached $\mathrm{Ph}\left(\mathrm{CH}_{2}\right)_{3} \mathrm{Ph}(\approx \mathrm{DPP})$ at saturation coverage $\left(7-9 \% h^{-1}\right) .2$ Since the rates of conversion of DPP and $\approx D P P$ are similar, surface-attachment does not perturb the initial reaction behavior in the decomposition of $\approx$ PPE-3.

The cracking of PPE is proposed to proceed by a free radical chain decomposition reaction, although a minor contribution from a concerted retro-ene reaction can not be completely ruled out. 8 The decomposition reaction is initiated by homolysis of the weak $\mathrm{C}-\mathrm{O}$ bond (bond dissociation energy estimated as ca. $\left.63 \mathrm{kcal} \mathrm{mol}^{-1}\right)^{12}$ to form 2-phenylethyl and phenoxy radicals. The radical chain propagation steps are show in eq 3 and 4 .

$$
\mathrm{PhO}+\mathrm{PhCH}_{2} \mathrm{CH}_{2} \mathrm{OPh} \rightarrow \mathrm{PhOH}+\mathrm{PhCHCH}_{2} \mathrm{OPh}
$$




$$
\mathrm{Ph} \stackrel{\bullet}{\mathrm{HCH}} \mathrm{H}_{2} \mathrm{OPh} \rightarrow \mathrm{PhCH}=\mathrm{CH}_{2}+\mathrm{PhO} \cdot
$$

In the thermolysis of $\approx$ PPE-3, a similar free radical decomposition reaction can be written to explain the formation of the products (eq 5-12). The reaction is initiated by the homolysis of the weak $\mathrm{C}-\mathrm{O}$ bond. The resulting radicals can abstract hydrogen from $\approx$ PPE- 3 to form a surface-attached 1-phenoxy-2-phenyl-2-ethyl radical (1) which can undergo $\beta$-scission to yield surface-attached styrene and the chain carrying phenoxy radical.

$$
\begin{aligned}
\approx \mathrm{PhCH}_{2} \mathrm{CH}_{2} \mathrm{OPh} & \rightarrow \approx \mathrm{PhCH}_{2} \mathrm{CH}_{2} \cdot+\mathrm{PhO} \cdot \\
\approx \mathrm{PhCH}_{2} \mathrm{CH}_{2} \cdot+\approx \mathrm{PhCH}_{2} \mathrm{CH}_{2} \mathrm{OPh} & \rightarrow \approx \mathrm{PhCH}_{2} \mathrm{CH}_{3}+\approx \mathrm{PhC} \mathrm{HCH}_{2} \mathrm{OPh} \\
\mathrm{PhO}+\approx \mathrm{PhCH}_{2} \mathrm{CH}_{2} \mathrm{OPh} & \rightarrow \mathrm{PhOH}+1 \\
1 & \rightarrow \approx \mathrm{PhCH}=\mathrm{CH}_{2}+\mathrm{PhO} \cdot
\end{aligned}
$$

Surface-attached $\mathrm{PhCH}_{3}$ and gas phase $\mathrm{PhCHO}$ can be formed by a free radical chain process shown in steps 9-12. Hydrogen abstraction at the aliphatic site forms 1-phenoxy-2-phenyl-1-ethyl radical (2). Although radical 1 is estimated to be more stable than 2 by ca. $7 \mathrm{kcal} \mathrm{mol}^{-1,12}$ there is precedence for the competitive formation of products from the thermodynamically less stable radical of tetralin (2-tetralyl radical) ${ }^{13}$ and 1,4-diphenylbutane (1,4-diphenyl-2-butyl radical) ${ }^{14}$ at these temperatures.

$$
\begin{aligned}
& \mathrm{PhO}+\approx \mathrm{PhCH}_{2} \mathrm{CH}_{2} \mathrm{OPh} \rightarrow \mathrm{PhOH}+\approx \mathrm{PhCH}_{2} \dot{\mathrm{C}} \mathrm{HOPh} \\
& 2 \\
& \approx \mathrm{PhCH}_{2} \dot{\mathrm{C}} \mathrm{HOPh} \rightarrow \approx \underset{\mathrm{Ph}}{\mathrm{PhCH}} \\
& \approx \underset{\mathrm{Ph}}{\mathrm{PhCH}_{2} \mathrm{CHO}} \rightarrow \approx \mathrm{PhCH}_{2} \cdot+\mathrm{PhCHO}
\end{aligned}
$$

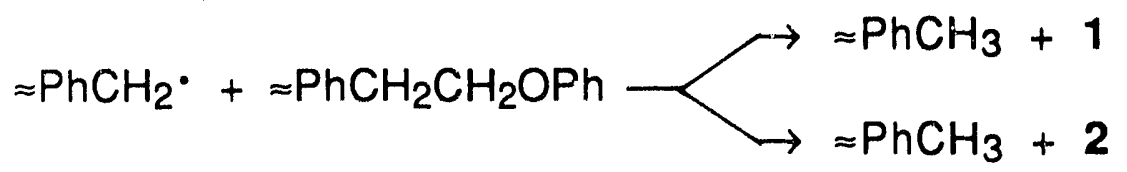

Radical 2 can undergo a 1,2-phenyl shift irom oxygen to carbon (eq 10). Analogous intramolecular 1,2-phenyl shifts have been reported in the thermal decomposition of phenetole $\left(\mathrm{PhOCH}_{2} \mathrm{CH}_{3}\right)^{15}$ and anisole at $400{ }^{\circ} \mathrm{C} .16$ $\beta$-scission of the rearranged radical affords benzaldehyde and the chain carrying surface-attached benzyl radical. Formation of $\approx \mathrm{PiCH}_{3}$ from $\mathrm{C}-\mathrm{C}$ homolysis of $\approx \mathrm{PPE}$, producing $\approx \mathrm{PhCH}_{2}{ }^{\circ}$ and $\mathrm{PhOCH}_{2}{ }^{\circ}$, is predicted to be small 
since the $\mathrm{C}-\mathrm{C}$ bond is estimated to be ca. $7 \mathrm{kcal} \mathrm{mol}^{-1}$ stronger than the corresponding $\mathrm{C}-\mathrm{O}$ bond in PPE.12 Furthermore, no anisole (from hydrogen abstraction by $\mathrm{PhOCH}_{2}{ }^{\circ}$ ) or benzyl alcohol (from 1,2-phenyl shift and hydrogen abstraction by $\mathrm{PhCH}_{2} \mathrm{O}^{\circ}$ ) was detected. Additional evidence for this previously undetected free radical pathway for the thermal degradation of PPE is found in the thermolysis of the $\approx \mathrm{PhOCH}_{2} \mathrm{CH}_{2} \mathrm{Ph}(\approx \mathrm{PPE}-1)$ at $375{ }^{\circ} \mathrm{C}$ in which $\approx \mathrm{PhOH}$ and $\mathrm{PhCH}=\mathrm{CH}_{2}$ are formed as the major products (ca. $80 \mathrm{~mol}$ $\%$ ) and $\approx \mathrm{PhCHO}$ and $\mathrm{PhCH}_{3}$ are formed as the minor products (ca. $20 \mathrm{~mol} \%$ ) indicating a similar free radical chain mechanism as described in steps 512 is occurring. 17

At this point, it is unclear whether the additional mechanistic steps (eq 912) required to rationalize the product distribution from the thermolysis of $\approx P P E$ are a consequence of restricted diffusion, or an undetected reaction pathway in the thermolysis of liquid phase PPE. However, these reactions may explain the formation of toluene at low conversions and the formation of 1,2-diphenylethane and benzyl phenyl ether at higher conversions (termination reactions of $\mathrm{PhCH}_{2}{ }^{\circ}$ ) which are reported for the thermal decomposition of PPE. 8 These steps may also be participating in the thermal decomposition of the homopolymers of 4-allylphenol and eugenol, which contain $\beta$-ether types linkages,18,19 The previous mechanism for the decomposition of PPE (steps 3 and 4$)^{9}$ could not explain the formation of $\mathrm{C}_{1}$-phenol and catechol (cresol, $\mathrm{m} / \mathrm{e} 108$ and 2-methoxy-4-methylphenol, $\mathrm{m} / \mathrm{e}$ 138). However, by inclusion of reactions analogous to those in steps 9 12, a reasonable free radical chain pathway is available for formation of these products.

\section{CONCLUSIONS}

Covalent attachment of organic compounds to an inert silica surface has proven useful in modeling the effects of restricted substrate diffusion on free radical decomposition reactions which may occur in coal as a consequence of its cross-linked macromolecular structure. Thermolysis of surface-attached phenethyl phenyl ether, as a model for ether linkages in lignin, has shown a previously undetected pathway for the free radical chain decomposition of PPE which affords surface-attached toluene and gas phase benzaldehyde. Additional studies into the role of the radical rearrangements and the origin of this new decomposition pathway in the thermal decomposition of $\approx$ PPE are currently under way.

\section{ACKNOWLEDGEMENTS}

This research was sponsored by the Division of Chemical Sciences, Office of Basic Energy Sciences, U. S. Department of Energy under contract DE-AC05- 
840R21400 with Martin Marietta Energy Systems, Inc. VMH was supported by Oak Ridge Associated Universities Undergraduate Research Participation Program.

\section{REFERENCES}

1. Buchanan, III, A. C.; Dunstan, T. D. J.; Douglas, E. C.; Poutsma, M. L. J. Am. Chem. Soc. 1986, 108, 7703.

2. Buchanan, III, A. C.; Biggs, C. A. J. Org. Chem. 1989, 54, 517.

3. (a) Britt, P. F.; Buchanan, IIi, A. C.; Biggs, C. A. Prep. Pap. -Am. Chem. Soc., Div. Fuel Chem. 1989, 34(2), 567. (b) Britt, P. F.; Buchanan, III, A. C., submitted for publication.

4. (a) Buchanan, III, A. C.; Britt, P. F.; Biggs, C. A. Energy \& Fuels 1990, 4, 415. (b) Buchanan, III, A. C.; Britt, P. F.; Biggs, C. A. Prep. Pap. -Am. Chem. Soc., Div. Fuel Chem. 1989, 34(4), 1317.

5. Buchanan, III, A. C.; Britt, P. F.; Poutsma, M. L. Prep. Pap. -Am. Chem. Soc., Div. Fuel Chem. 1990, 35(1), 217.

6. Solomon, P. R.; Serio, M. A.; Deshpande, G. V.; Kroo, E.; Schobert, H.; Burgess, C. Prep. Pap. -Am. Chem. Soc., Div. Fuel Chem. 1989, 34(3), 803.

7. Suuberg, E. M.; Lee, D.; Larsen, J. W. Fuel 1985, 64, 1668.

8. Klein, M. T.; Virk, P. S. Ind. Eng. Chem. Fundam. 1983, 22, 35.

9. (a) Gilbert, K. E.; Gajewski, J. J. J. Org. Chem. 1982, 47, 4899. Gilbert, K. E. J. Org. Chem. 1984, 49, 6.

10. Korobkov, V. Y.; Grigorieva, E. N.; Bykov, V. I.; Senko, O. V.; Kalechitz, I. V. Fuel 1988, 67, 657.

11. Cassidy, P. J.; Jackson, W. R.; Larkins, F. P. Fuel 1983, 62, 1404.

12. (a) Benson, S. W. Thermoctemical Kinetics, 2nd ed.; Wiley-Interscience: New York, 1976. (b) McMillen, D. F.; Golden, D. M. Annu. Rev. Phys. Chem. $1982,33,493$.

13. (a) Franz, J. A.; Camaioni, D. M. J. Org. Chem. 1980, 45, 5247. (b) Benjamin, B. M.; Hagaman, E. W.; Raaen, V. F.; Collins, C. J. Fuel 1979, 58, 386.

14. Poutsma, M. L.; Dyer, C. W. J. Org. Chem. 1982, 47, 4903.

15. Collins, C. J.; Roark, W. H.; Raaen, V. F.; Benjamin, B. M. J. Am. Chem. Soc. 1979, 101, 1877.

16. Afifi, A. I.; Hindermann, J. P.; Chornet, E.; Overend, R. P. Fuel 1989, 68, 498.

17. Britt, P. F.; Fox, Jr., J. B., unpublished results.

18. McMillen, D. F.; Malhotra, R.; Serio, M. A. Prep. Pap. -Am. Chem. Soc., Div. Fuel Chem. 1990, 35(2), 430.

19. These polymers presumable contain the analogous $\mathrm{C}-\mathrm{C}-\mathrm{O}$ linkage; However, conclusive evidence for the structures of the polymers is not currently available. 


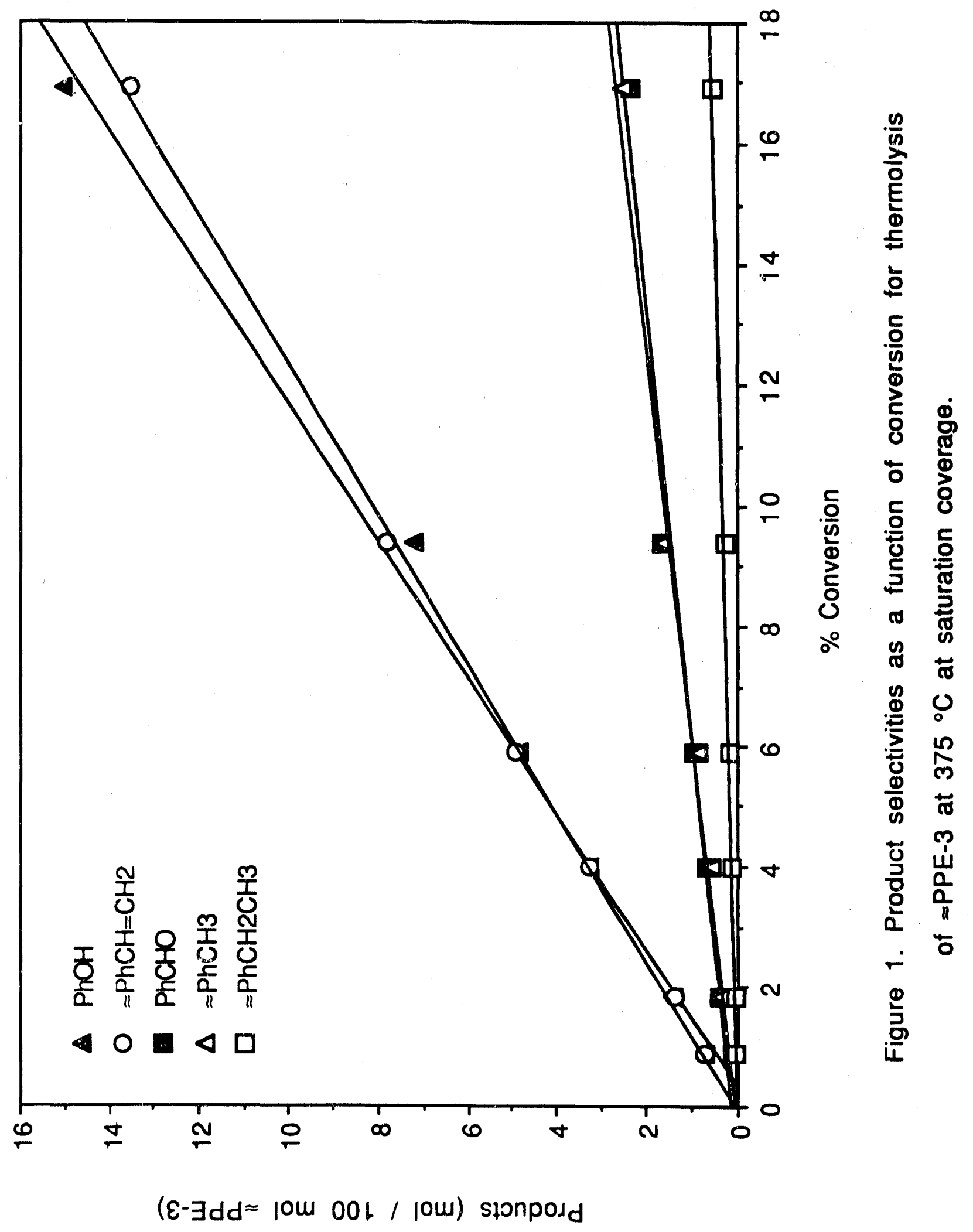



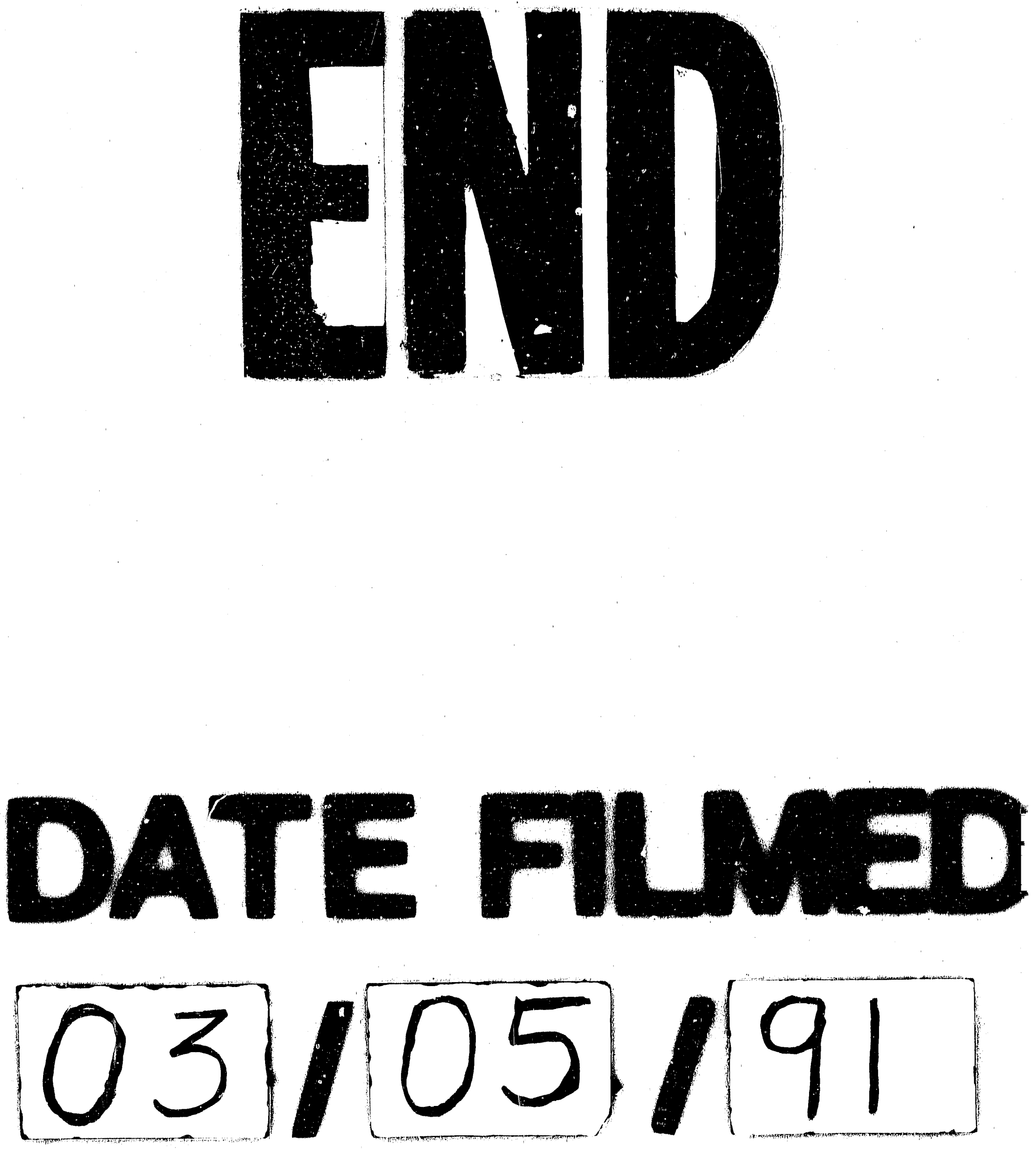
